ANDRZEJ BATOR ${ }^{1}$, PRZEMYSŁAW KACZMAREK ${ }^{2}$

\title{
Kim ma być wychowanek akademii prawniczej? \\ O perspektywach budowania edukacji prawniczej wokół konstytucji
}

\section{Streszczenie}

Prezentowany artykułu powstał na tle obserwacji bieżących polskich sporów polityczno-prawnych wokół Konstytucji. Poszukując przyczyn różnic w pojawiającej się argumentacji, zwróciliśmy uwagę na zagadnienie edukacji konstytucyjnoprawnej. Postawione zadanie przedstawiliśmy w dwóch etapach. W pierwszym omówiliśmy wyróżniane w teorii społecznej modele edukacji. Punktem wyjścia uczyniliśmy model strukturalno-funkcjonalny oraz jego krytykę z perspektywy teorii konfliktowych, interpretatywnych i krytycznych. Następnie zaprezentowana została ewolucja instytucji prawno-administracyjnych w świetle konfliktu między oczekiwaniem ich otwartości na wymiar etyczny i polityczny a roszczeniem integralności i spójności. W tym celu skorzystaliśmy z propozycji Philippe Noneta i Philipa Selznicka. W drugim etapie przybliżyliśmy trzy koncepcje konstytucji i konstytucjonalizmu. Za modelowe przykłady posłużyły nam poglądy Hansa Kelsena, Carla Schmitta oraz amerykańska doktryna judicial review. Propozycje te, jak staraliśmy się wykazać, można przedstawić jako punkty oparcia dla trzech wizji edukacji konstytucyjnoprawnej. W artykule nie poprzestaliśmy tylko na prezentacji modeli edukacji i rekonstrukcji wizji edukacji konstytucyjnej. Usiłowaliśmy również, mając na uwadze doświadczenia polskiej debaty wokół Konstytucji, wykazać, że doktryna judicial review otwiera obiecującą przestrzeń dla rewaluacji nauki i praktyki (a więc i dydaktyki) konstytucyjnoprawnej.

Słowa kluczowe: prawo, polityka, instytucja prawna, edukacja, konstytucja, konstytucjonalizm

1 Prof. dr hab. Andrzej Bator - kierownik Katedry Teorii i Filozofii Prawa Wydziału Prawa, Administracji i Ekonomii Uniwersytetu Wrocławskiego; e-mail: andrzej.bator@uwr.edu.pl; ORCID: 0000-0003-4772-7920.

2 Dr hab. Przemysław Kaczmarek - Katedra Teorii i Filozofii Prawa Wydziału Prawa, Administracji i Ekonomii Uniwersytetu Wrocławskiego; e-mail: przemyslaw.kaczmarek@uwr.edu.pl; ORCID: 0000-0002-3436-4043. 


\title{
What is a law academy's alumnus to be like? On the prospects of developing a legal education around the constitution
}

\begin{abstract}
This article has arisen from the observations of the current Polish political and legal disputes over the Constitution. In pursuing the reasons for the different lines of argument presented, we have brought to attention the issue of education in constitutional law. We have presented the task set over two stages. In the first stage we discussed the educational models as expounded in the social theory. As a starting point, we adopted the structural-functional model and its criticism along the lines of the conflict-theory, interpretative and critical theories. Subsequently, the evolution was presented of administrative-law institutions in the light of the conflict between the expected openness to the ethical and political dimensions and the integrity and coherence claims. To this end, we followed the proposals of Philippe Nonet and Philip Selznick. In the second stage, we reviewed three conceptions of the constitution and constitutionalism. The views of Hans Kelsen, Carl Schmitt as well as the American judicial review doctrine served as model examples. These proposals, as we have tried to demonstrate, can be presented as the cornerstones of the three visions of constitutional-law education. In this article, we did not satisfy ourselves in presenting the educational models and reconstructing the vision of constitutional education. We have also attempted to demonstrate, bearing in mind the experiences of the Polish debate over the Constitution, that the judicial review doctrine opens up a promising sphere for a revaluation of both the theory and practice (and hence, the didactics) of constitutional law.
\end{abstract}

Keywords: law, politics, legal institution, education, constitution, constitutionalism 


\section{Wprowadzenie}

Edukację przedstawia się często jako proces kształcenia, którego celem jest przygotowanie człowieka do wykonywania określonej roli społecznej. Florian Znaniecki przybliża dwa pola badawcze tak rozumianej edukacji ${ }^{3}$. Pierwsze z nich dotyczy społecznych uwarunkowań, mających wpływ na proces wychowawczy, z kolei drugie pole badawcze dotyczy uwarunkowania instytucjonalnego. W ich obrębie ważne jest pytanie o sposób modelowania wizerunku wychowanka instytucji. W tym zakresie rozpościerają się dwa dylematy teoretyczne związane z budowaniem instytucji ${ }^{4}$. Pierwszy z nich dotyczy relacji między sprawstwem jednostki a strukturą społeczną. Czy działanie, jakie wykonujemy, jest determinowane przez czynniki instytucjonalno-społeczne, czy też jest wyrazem sprawstwa podmiotowego? Z kolei drugi dylemat dotyczy napięcia między konsensem a konfliktem społecznym. Jedni autorzy podkreślają porządek i harmonię społeczną, w której podejmowane jest działanie. $\mathrm{W}$ tym ujęciu konsens społeczny jest cechą instytucji społecznych. Inni z kolei zwracają uwagę na sytuacje konfliktu w praktykach społecznych. Nawet jeśli nie dochodzi w nich do otwartych konfrontacji, to i tak mamy do czynienia z głębokimi konfliktami interesów.

W jaki sposób rozstrzyga się wskazane dwa dylematy w budowaniu wizerunku wychowanka instytucji, to pytanie, na które odpowiedź wyznacza zakres poniższych rozważań. Realizując przedstawione zadanie, najpierw uwzględnimy aspekt społeczny. W tym celu odwołamy się do ustaleń Waltera Feinberga i Jonasa F. Soltisa, przedstawiając trzy ujęcia edukacji: strukturalno-funkcjonalistyczne, konfliktowe $\mathrm{i}$ interpretatywne ${ }^{5}$. Następnie - $\mathrm{w}$ ramach aspektu instytucjonalnego - zaprezentujemy ustalenia Philippe'a Noneta i Philipa Selznicka dotyczące rozwoju instytucji prawnych. Przywołani badacze wyróżniają trzy modele kształtowania instytucji prawnych: represyjny, autonomiczny i responsywny.

Tak uporządkowany materiał badawczy - przedstawiony w pierwszej części artykułu - posłuży nam następnie jako podstawa dla próby scharakteryzowania

3 F. Znaniecki, Socjologia wychowania, t. 1, Warszawa 2001, s. 21.

4 A. Giddens, P.W. Sutton (współpraca), Socjologia, wydanie nowe, Warszawa 2012, s. 85-90.

5 W. Feinberg, J.F. Soltis, Szkoła i społeczeństwo, Warszawa 2000. Taką strukturę przyjmuje również Roland Meighan (z udziałem Lena Bartona i Stephena Walkera), Socjologia edukacji, Torun 1993, cz. IV; P. Mikiewicz, Socjologia edukacji. Teorie, koncepcje, pojęcia, Warszawa 2016. 
uwarunkowań edukacji prawno-konstytucyjnej, a zarazem, poprzez ukazanie potencjalnych alternatyw, odpowiedzi na odpowiedzi na pytanie, o możliwe kierunki jej ewolucji. Pomysł aplikowania przywołanych wyżej koncepcji socjologicznych do materii prawa konstytucyjnego i dydaktyki w tym obszarze powstał na tle obserwacji bieżących polskich sporów polityczno-prawnych. Bezsporna doniosłość, a zarazem wręcz rudymentarna rozbieżność argumentacji przywoływanej przez strony tego sporu, rodzi pytanie o jego teoretyczne i filozoficzne uwarunkowania. Bo to przecież ukształtowana w nauce i doktrynie prawa konstytucyjnego wiedza o ustawie zasadniczej rzutuje na to, jaką wizję, jaką koncepcję (filozofię) konstytucji i konstytucjonalizmu zaoferują profesorowie swoim studentom, a ci drudzy z kolei aplikować i upowszechniać będą w swoim przyszłym życiu zawodowym. Wykład akademicki odbierany jest przez studentów poprzez akceptację, autorytet instytucji (uniwersytetu), którego wykładowcy stanowią zasadniczy komponent. Dlatego tak istotne jest to, czy student otrzyma jakiś prosty, zdogmatyzowany porządek wiedzy o danej dziedzinie, czy też zostanie wprowadzony w pewien dyskurs, ukazujący złożony, bywa że kontrowersyjny u samych podstaw, charakter prezentowanej problematyki. Ta druga ścieżka wydaje się być obecnie jedyną sensowną w przypadku nauczania prawa konstytucyjnego. Stwarza nie tylko szansę na zrozumienie i zdiagnozowanie przyczyn rozejścia się obecnych polskich narracji o konstytucji, a także na ukazanie kierunków ewentualnych zmian dla dotychczasowego standardu uprawiania nauki i nauczania prawa konstytucyjnego. Kwestie te będą przedmiotem rozważań w drugiej części niniejszego artykułu.

\section{Modele dydaktyki a ewolucja instytucji prawnych}

\section{Socjologie edukacji}

W teorii społecznej dość powszechnie przyjmuje się rozróżnienie na trzy ujęcia edukacji, zaproponowane przez W. Feinberga i J.F. Soltisa ${ }^{6}$. Przedstawiają oni edukację $\mathrm{w}$ ujęciu: strukturalno-funkcjonalistycznym, konfliktowym, interpretatywnym ${ }^{7}$. Omawiając je, punktem wyjścia uczynimy przedstawienie modelu strukturalno-funkcjonalistycznego. Następnie spojrzymy na ten model z perspektywy konfliktowej oraz interpretatywnej.

6 W. Feinberg, J.F. Soltis, op. cit., s. 14 i n.

7 Wymienione podejścia są wewnętrznie zróżnicowane. Tytułem przykładu w podejściu interpretatywnym można wyróżnić ujęcie interakcyjne, fenomenologiczne, etnometodologiczne. 
Strukturalny funkcjonalizm zakłada, że działanie w świecie instytucji oparte jest na intersubiektywnie rozumianym konsensusie. $Z$ tego powodu strukturę instytucjonalną charakteryzuje wewnętrzna spójność elementów. Stanowisko to jest konsekwencją przyjęcia założeń o ontologicznym holizmie oraz metodologicznym antyredukcjonizmie. Na ich podstawie rekomenduje się postać społeczeństwa jako organizmu złożonego z wielu związanych ze sobą elementów, a instytucji przypisuje się status faktu społecznego. Oznacza to przyjęcie stanowiska, że struktury wyznaczają działanie jednostki i kształtują sposób postrzegania rzeczywistości. W tym sensie struktura społeczna ma wpływ na osobowość człowieka.

Systemowe ujęcie rzeczywistości społecznej dopełniane jest pojęciem funkcji, którym strukturaliści posługują się na oznaczenie wpływu jednego elementu systemu na drugi. Sugeruje to, że poszczególnych części systemu nie powinno rozpatrywać się niezależnie od siebie ${ }^{8}$. Rozumienie ich zakłada postrzeganie części jako fragmentu czegoś większego. Za pomocą obu wymienionych kategorii pojęciowych działanie w instytucji przedstawia się jako spójne, ukierunkowane na realizację określonych celów. Takie założenie oznacza danie pierwszeństwa temu, co niezmienne, stałe, przed tym, co przemijające, jednostkowe. $W$ ten sposób buduje się obraz rzeczywistości społecznej, który wyznacza sposób myślenia i rozwiązywania konkretnych problemów. Celem edukacji w perspektywie strukturalno-funkcjonalistycznej jest utrzymywanie równowagi między poszczególnymi praktykami społecznymi i racjonalizowanie tak rozumianego ładu społecznego. W tym celu edukacji przypisuje się trzy funkcje: socjalizacyjną, alokacyjną i selekcyjną ${ }^{9}$.

Pierwsza z wyróżnionych funkcji zakłada zadanie wychowawcze. Realizując je, przyjmuje się, że celem edukacji jest przygotowanie obywatela do wykonywania określonej roli społecznej. Przygotowanie to odbywa się na poziomie aksjologicznym oraz wiedzy przedmiotowej. Z jednej strony, celem edukacji jest przyjęcie przez wychowanków instytucji określonych wartości jako własnych. Z drugiej zaś strony, socjalizacja ta polega na wypracowaniu narzędzi, które należy stosować w praktyce instytucjonalnej. Uznanie wartości za intersubiektywne oraz wiedzy przedmiotowej za obiektywnie daną, przyczynia się do stabilizacyjnej funkcji praktyki społecznej. Na dalszym etapie edukacji następuje proces specjalizacji, który przygotować ma wychowanka instytucji do wykonywania konkretnego zawodu w ramach wcześniej obranej roli społecznej. Mechanizm ten dobrze ilustruje edukacja prawnicza, w której studia mają przygotowywać do wykonywania zawodów prawniczych i urzędniczych, a aplikacje korporacyjne i państwowe do sprawowania danej profesji, np. adwokata, sędziego. Pokonywanie kolejnych etapów

\footnotetext{
8 P. Baert, F. Carreira da Silva, Teorie społeczne w XX wieku i dzisiaj, Kraków 2013, rozdz. 1.

9 Przedstawiamy za Piotrem Mikiewiczem, zob. Socjologia edukacji.., s. 86 i n.
} 
socjalizacji zakłada coraz silniejsze wkraczanie w normatywny świat znaczeń i wartości, które są reprodukowane przez kulturę zawodową. Takie metodyczne działanie zakłada, że doświadczenie, jakie nabywamy w procesie socjalizacji, staje się podstawowym nie tylko dla sposobu naszego postępowania, ale i naszej tożsamości. Można powiedzieć, że funkcja socjalizacyjna oparta jest na założeniu, że to instytucja modeluje obraz wychowanka i według tego wzorca odbywa się proces edukacji na poszczególnych jej etapach ${ }^{10}$. Jak ujmuje to Piotr Mikiewicz: „Szkoła jest tu widziana jako omnipotentna. Ma narzędzia, personel i program, na podstawie którego urabia jednostki (...)"11.

Drugą z funkcji edukacji w modelu strukturalno-funkcjonalistycznym jest alokacja. Zwraca ona uwagę na pozycję jednostki w strukturze instytucjonalnej, a dokładniej na proces uzyskiwania kwalifikacji do wykonywania odkreślonej profesji. W celu lepszego zobrazowania funkcji alokacyjnej zwróćmy uwagę na pojęcie ruchliwości w ujęciu pionowym i poziomym. W pierwszym z wyróżnionych ujęć ruchliwość zakłada możliwość przechodzenia jednostki między pozycjami w ramach hierarchicznie ujętej struktury. Z kolei ruchliwość pozioma zakłada, że możliwe jest przejście między różnymi grupami społecznymi bez zmiany pozycji społecznej, np. w wyniku migracji. Strukturalny funkcjonalizm w większym stopniu koncentruje uwagę na ruchliwości pionowej. Jej narzędziem jest edukacja. Przedstawianie edukacji jako nieustawicznego procesu jest racjonalizowane osiąganiem kolejnych pozycji w strukturze społecznej. Edukację czyni się odpowiedzialną za dostarczanie instytucji osób najlepiej predysponowanych do wykonywania przewidzianej roli.

Wskazany wyżej aspekt edukacji odsłania jej funkcję selekcyjną. Jest ona trzecią z kolei, którą przypisuje się systemowi nauczania w modelu strukturalno-funkcjonalistycznym. Funkcja ta opiera się na założeniu, że celem edukacji jest ocena kandydatów do wykonywanego zawodu. Z tego też powodu proces kształcenia i sposób adaptacji wiedzy podlega ocenie przez instytucję. Przedmiotem tej oceny są dotychczasowe osiągnięcia kandydata oraz jego predyspozycje do wykonywania zawodu ${ }^{12}$.

Wymienione trzy funkcje kształcenia oparte są na logice społeczeństwa nowoczesnego $^{13}$. Zakłada ona standaryzację i uniformizację rozwiązań jako projektowany

\footnotetext{
10 Ibidem, s. 89.

11 Ibidem, s. 90.

12 Ibidem, s. 107.

13 Taką charakterystykę przedstawia Piotr Mikiewicz, zob. Oblicza socjologii edukacji - w stronę syntetycznego modelu analiz, „Edukacja” 2017, 3, s. 12.
} 
efekt systemu edukacyjnego. Taki obraz nauczania jest poddawany krytyce z perspektywy konfliktowej. W. Feinberg i J.F. Soltis, przedstawiając to ujęcie, zauważają:

Funkcjonaliści żywią przekonanie, że zmiany społeczne i oświatowe napędza postępowe $w$ istocie dążenie do rozwoju technicznego i społecznej integracji. Dla teorii konfliktowej taką siłą napędową jest niekończąca się walka pomiędzy rozmaitymi grupami, toczona o władzę i pozycję, a szkolnictwo jest $\mathrm{w}$ tej walce znaczącym orężem ${ }^{14}$.

Według ujęcia konfliktowego społeczeństwo nie jest widziane harmonijnie, a instytucje nie są fundowane na konsensusie, ale są areną walki między różnymi grupami interesu. Walka ta toczona jest o władzę, a edukację wspiera ośrodek polityczny, który ją sprawuje. Uzasadniając to stanowisko, zwraca się uwagę na następujące bolączki procesu edukacji rekomendowane przez model strukturalno-funkcjonalistyczny ${ }^{15}$.

Pierwszym zarzutem jest zarzut legitymizowania porządku politycznego. Władza wymaga uprawomocnienia i dlatego używa edukacji jako narzędzia do kształtowania świadomości czy też - mówiąc w języku teorii konfliktowych - fałszywej świadomości. Piotr Mikiewicz, odwołując się do dorobku Karola Marksa i jego kontynuatorów, tak ją charakteryzuje:

Fałszywa świadomość jest efektem pracy elit, które produkują ideologie i narzucają je klasom podporządkowanym, w ten sposób gwarantując sobie uprzywilejowaną pozycję i niwelując potencjał społecznego buntu' ${ }^{16}$.

Edukacja, tak jak ją przedstawiają funkcjonaliści, jest dla autorów krytycznych strażnikiem podziału władzy i wynikających z niej przywilejów. Z twierdzeniem tym związany jest drugi zarzut, a mianowicie, że edukacja jest narzędziem reprodukcji istniejących stosunków społecznych. Jej celem w procesie socjalizacji jest odtwarzanie hierarchii społecznej. Przedstawiając ten mechanizm, można odwołać się do rozróżnienia na funkcje jawne i ukryte. W warstwie deklarowanej celem szkoły jest przekazywanie określonej wiedzy. Zdobycie jej ma zapewnić wychowankom instytucji prawidłowe wykonywanie roli społecznej. W warstwie ukrytej z kolei podkreśla się, że treść tej wiedzy nie jest neutralna. Ma ona przygotować kandydata do pełnienia z góry przewidzianej roli. Zadaniem edukacji jest zatem:

\footnotetext{
14 W. Feinberg, J.F. Soltis, Szkoła i społeczeństwo..., s. 44.

15 P. Mikiewicz, Socjologia edukacji..., s. 146 i n.

16 Ibidem, s. 147.
} 
"dostarczanie ludziom przekonywujących uzasadnień, żeby postępować tak, jakby bez tego nie byli może skłonni postępować i podtrzymywali w ten sposób obecny system stosunków produkcji i władzy"17.

Jednym z autorów, który poddaje krytyce strukturalno-funkcjonalistyczny model edukacji, jest Pierre Bourdieu ${ }^{18}$. Francuski socjolog zwraca uwagę na pojęcie pola jako ustalonej gry konwencji. W polu edukacji deklarowaną funkcją kształcenia jest przygotowanie człowieka do odgrywania z góry przewidzianej roli społecznej, a z kolei funkcją ukrytą jest dążenie do zatracenia się jednostki w zastanych regułach postępowania. Ukrytym celem systemu nauczania staje się marginalizacja podmiotowości człowieka w roli i uznanie zastanych konwencji jako czegoś obiektywnego, niepodlegającego problematyzacji. Natomiast pod pojęciem dyspozycji do wykonywania roli społecznej ukrywa się pojęcie habitusu, tj. społecznie ukształtowanej natury człowieka. Zgodnie z tą metaforyką działanie jednostki jest determinowane przez strukturalne nakazy roli. Podmiotowość gubi się w strukturze społecznej. Język, jako podstawowe narzędzie komunikacji, buduje określony obraz rzeczywistości. Staje się on na skutek procesu kształcenia obiektywną rzeczywistością, którą przyjmujemy, wykonując rolę. Z pokonywaniem kolejnych stadiów socjalizacji łączy się dostęp do różnych postaci kapitału, np. ekonomicznego, kulturowego. Nabywanie ich powoduje wzrost znaczenia zastanych reguł gry jako tych, które pozwalają utrzymać posiadany kapitał, a w konsekwencji obowiązujący porządek społeczno-ekonomiczny ${ }^{19}$.

Model strukturalno-funkcjonalistyczny dominuje również w polskim procesie kształcenia ${ }^{20}$. Jest podawany w wątpliwość nie tylko z pozycji teorii konfliktowych, ale także interpretatywnych ${ }^{21}$. Tutaj z kolei źródłem krytyki jest perspektywa makrospołeczna, przedstawiająca edukację jako narzędzie utrzymywania równowagi społecznej. W zamian kierunek interpretatywny proponuje perspektywę mikrosocjologiczną. Na jej podstawie objaśnianie rzeczywistości społecznej dokonuje się za pomocą pojęcia interakcji między członkami grupy społecznej oraz jednostką a strukturą instytucjonalną. Takie rozstrzygnięcie pozwala na przypisywanie działaniu charakteru zarówno podmiotowego, jak i reprodukcyjnego.

17 W. Feinberg, J.F. Soltis, op. cit., s. 55; por. też D. Kennedy, Legal Education and the Reproduction of Hierarchy, "Journal of Legal Education” 1982, 32(4).

18 P. Bourdieu, J.D. Passeron, Reprodukcja. Elementy teorii systemu nauczania, Warszawa 2006.

19 E. Neyman, Wywiad z profesorem Pierre'em Bourdieu, [w:] P. Bourdieu, J.D. Passeron, op. cit., s. 346; P. Mikiewicz, Oblicza socjologii edukacji..., s. 13.

20 Z. Kwieciński, Dynamika funkcjonowania szkoły. Studium empiryczne z socjologii, Toruń 1995; J. Zapała, Korporacje prawnicze jako agenda socjalizacji. Rozważania na przykładzie samorządu notarialnego, [w:] H. Izdebski, P. Skuczyński (red.), Etyka prawnicza. Stanowiska i perspektywy 2, Warszawa 2011.

21 P. Mikiewicz, Socjologia edukacji..., część IV. 
Oznacza to nie tylko przeformułowanie modelu poznania rzeczywistości społecznej (poprzez przezwyciężenie opozycji podmiot-przedmiot poznania i powiązanie myśli z działaniem), ale i podkreślenie roli jednostki w jej współtworzeniu. Na poziomie ontologicznym przełamuje to twierdzenie, zgodnie z którym jednostka i struktura społeczna to dwa osobne byty. Dylemat "jednostka czy struktura" zostaje zniesiony poprzez przyjęcie perspektywy dualistycznej. Zakłada ona, że oba wymienione aspekty dopełniają się i dlatego nie sposób jest badać rzeczywistości (społecznej, instytucjonalnej), redukując ją do jednego z nich.

Według P. Mikiewicza, przenosząc te rozstrzygnięcia na grunt edukacji: „odkrywamy szkołę nie jako mechanizm selekcji i alokacji jednostek w systemie społecznym, ale jako zbiorowość ludzi, którzy wchodzą ze sobą w interakcje i wspólnie definiują rzeczywistość szkolną" ${ }^{22}$. Widzimy zatem szkołę jako strukturę ról społecznych, których wykonawcy wchodzą we wzajemne interakcje. Ramę dla dokonywanych działań wyznacza struktura wykonywanych ról, która pozostawia miejsce dla indywidualności działających aktorów społecznych i sytuacyjności rozpatrywanej sprawy. O ile zatem model strukturalno-funkcjonalistyczny zwraca uwagę na funkcję edukacji w systemie społecznym, o tyle kierunek interpretatywny koncentruje się na działaniu aktorów procesu edukacyjnego. Badanie tego procesu może być ukierunkowane na odsłanianie tego, co na skutek rutynowego działania czy też myślenia instytucjonalnego w poszczególnych sferach aktywności jest zasłonięte. Można jednak przyjąć inną perspektywę, której celem jest opis standardów działania w praktyce społecznej. Przyjmując pierwszą z wymienionych perspektyw, korzysta się z pojęcia instytucji totalnej Ervinga Goffmana, wskazując na element władzy w procesie dydaktycznym nauczyciela nad uczniami oraz stopień regulowania życia jednostki w życiu codziennym przez świat instytucji. W szkole, podobnie jak w Goffmanowskiej instytucji totalnej, można zaobserwować podział na dwie grupy: kontrolowanych i kontrolujących. Warto w tym kontekście wyróżnić za F. Znanieckim dwa modele szkoły: zamknięty i otwarty ${ }^{23}$. Zamknięty model szkoły fundowany jest na roszczeniu, którego celem jest oddziaływanie na wszystkie sfery aktywności ucznia. Z kolei otwarty model szkoły zakłada, że doświadczenie edukacyjne jest tylko jednym z czynników, które ma kształtować tożsamość człowieka, występującego w roli nauczyciela czy też ucznia.

Na kanwie badań prowadzonych w obszarze ujęcia konfliktowego oraz przede wszystkim interpretatywnego coraz silniejszą pozycję zdobywa prąd intelektualny

22 Ibidem, s. 203.

23 F. Znaniecki, op. cit., s. 102-114. 
określany mianem nowej socjologii edukacji albo edukacji krytycznej ${ }^{24}$. Nurt ten przedstawia szkołę w dwóch aspektach ${ }^{25}$.

Po pierwsze, nawiązując do ujęcia konfliktowego, rozpatruje system edukacji jako narzędzie selekcji osób, legitymizowania określonej aktywności polityczno-kulturowej. Jak odnotowuje Peter McLaren, polityka kulturalna, którą rekomenduje system nauczania: „zawsze sprzyja określonym relacjom władzy, praktykom społecznym i formom wiedzy, reprodukującym konkretne wizje przeszłości, teraźniejszości i przyszłości" 26 .

Po drugie, zwraca uwagę na szkołę jako instytucję, której celem jest budowanie tożsamości uczniów i nauczycieli. W badaniu tym nie tyle akcentuje się kwestię interakcji, sytuacji działania, ile samoświadomość podmiotu działającego. Stąd też kluczowym pojęciem staje się refleksyjność. W jej perspektywie pojęcie interakcji przedstawia się nie tyle w kontekście zachowania autonomii człowieka w procesie kształcenia, ale raczej świadomości uwikłania i konieczności ekspozycji ważnych aksjologicznie momentów, które to uwikłanie czynią niebezpieczne tak dla jednostki, jak funkcjonowania systemu edukacyjnego. Obok pojęcia refleksyjności ważnym pojęciem staje się odpowiedzialność ${ }^{27}$. W jej świetle przedstawiany jest status nauczyciela oraz ucznia. Obie wymienione figury "nauczyciela" i „ucznia” przedstawia się $\mathrm{w}$ perspektywie odpowiedzialności retrospektywnej oraz prospektywnej. Nauczyciel odpowiedzialny jest za realizację treści programowych (aspekt retrospektywny), ale jednocześnie odpowiada za sposób ich przedstawiania, a także rozwój akademii (aspekt prospektywny). W edukacji krytycznej uczeń nie jest biernym odbiorcą wiedzy przedmiotowej, ale powinien aktywnie uczestniczyć w procesie kształcenia. Stąd też coraz ważniejsze staje się nie to, czego uczymy, ale jak uczymy. Wyrazem tej zmiany jest zainteresowanie nowymi metodami kształcenia, np. case study, pervasive method.

Warto w tym miejscu również odnotować, że ujęcie krytyczne zakłada, $\mathrm{iz}^{28}$ :

1) edukacja jest działalnością zaangażowaną politycznie i może stać się narzędziem indoktrynacji określonych ideologii,

2) edukacja jest działalnością zaangażowaną etycznie, rekomendując określone wartości, może marginalizować inne,

3) edukacja może być uwikłana w odtwarzanie relacji społecznych i ich legitymizowanie.

24 P. Mikiewicz, Socjologia edukacji..., s. 242 i n.

25 P. McLaren, Życie po szkołach. Wprowadzenie do pedagogiki krytycznej, Wrocław 2015, s. 225.

26 Ibidem, s. 226.

27 P. Mikiewicz, Socjologia edukacji..., s. 244.

28 Ibidem, s. 245. 
Edukacja krytyczna podważa słuszność strukturalno-funkcjonalistycznego modelu edukacji w dwóch aspektach. Po pierwsze, za ujęciem interpretatywnym, rekomenduje perspektywę mikrosocjologiczną, która koncentruje uwagę na sieci relacji, $\mathrm{w}$ jakich uczestniczmy w procesie kształcenia. Po drugie, za ujęciem konfliktowym, odsłania ideologiczny wymiar edukacji. W tym zakresie zwraca uwagę na etyczny i polityczny wymiar edukacji. Wymiar etyczny pozwala dostrzec sytuacyjność i indywidualność relacji, w jakich uczestniczymy w procesie dydaktycznym. Ponadto zwraca uwagę na refleksyjność, odpowiedzialność, podmiotowość głównych aktorów procesu kształcenia, tj. nauczyciela i ucznia. Mając to na uwadze, edukacja krytyczna podaje w wątpliwość strukturalno-funkcjonalistyczny model kształcenia. Źródłem tej wątpliwości jest krytyka:

1) wizerunku wychowanka instytucji, którego działanie sprowadza się do dostosowania się do strukturalnych nakazów roli,

2) czynienia doświadczenia instytucjonalnego podstawowym nie tylko w procesie edukacji, ale i dla regulacji i oceny pozostałych sfer aktywności zarówno nauczyciela, jak i ucznia,

3) zasłaniania wymiaru ideologicznego, a w konsekwencji braku przedstawiania treści przekazywanej wiedzy jako zaangażowanej w rekomendowanie określonej wizji praktyki społecznej, a także wychowanka instytucji.

Z kolei w wymiarze politycznym edukacja krytyczna stawia sobie za cel przemienienie antagonizmu w agonizm, tj. uznanie opozycyjności interesów za coś nieuchronnego. $Z$ tego też powodu poddaje krytyce służebną funkcję systemu kształcenia wobec porządku społeczno-ekonomiczno-politycznego ${ }^{29}$.

\section{Trzy modele instytucji prawnych}

Stanowisko, które przyjmujemy za F. Znanieckim, zakłada, że o procesie kształcenia, modelowania wizerunku wychowanka instytucji można mówić w aspekcie społecznym oraz instytucjonalnym. O ile przedstawione wyżej obrazy edukacji odsłaniają aspekt społeczny, o tyle teraz przejdziemy do ustaleń w ramach drugiego z wymienionych aspektów. W tym celu korzystamy z propozycji P. Noneta i P. Selznicka przedstawiającej rozwój instytucji prawno-administracyjnych w świetle trzech modeli: represyjnego, autonomicznego i responsywnego. Kryterium ich wyróżnienia jest interesujące nas napięcie między otwartością instytucji na aspekt

29 M. Zemło, Nowa socjologia edukacji, Białystok 1996, s. 10. 
etyczny i polityczny a zachowaniem integralności rozumianej jako spójność praktyki instytucjonalnej ${ }^{30}$. Napięcie to ujawnia dwa dylematy:

1) na ile instytucje prawne mają być odrębne, autonomiczne wobec innych subświatów instytucjonalnych?

2) na ile wykonawca roli zawodowej ma mieć wpływ na sposób działania, a na ile jego postępowanie jest determinowane przez zewnętrzne czynniki?

W pierwszym przypadku pytamy o relacje prawa wobec innych subświatów instytucjonalnych, takich jak polityka, etyka. Z kolei w drugim, kluczowe jest pytanie o miejsce jurysty w prawniczym subświecie. W naszym przekonaniu pytania te są bliskie dylematom związanym z modelowaniem obrazu wychowanka instytucji w procesie kształcenia.

W modelu represyjnym zakłada się, że prawo jest wyrazem woli suwerena politycznego ${ }^{31}$. Prawo jest instrumentalnie podporządkowane realizacji polityki rządzących. Celem prawa jest zatem legalizacja porządku politycznego. Prawa i wolności obywatelskie podlegają ochronie, o ile są zgodne z interesem ośrodka politycznego sprawującego władzę. Takie ujęcie instytucji prawnych przewiduje dla prawnika rolę bezwolnego narzędzia, podporządkowanego rozstrzygnięciom władzy ustawodawczej. Represyjny model charakteryzuje adaptacja instytucji prawnych do politycznego środowiska. Instytucje prawne nie zachowują niezależności wobec innych praktyk społecznych, a ośrodek władzy politycznej sprawuje pełną kontrolę nad prawem.

Z kolei model autonomiczny można przedstawić w następujący sposób: po pierwsze, prawo ma zachować separację wobec świata polityki, zgodnie z trójpodziałem władzy. Konsekwencją tego będzie unikanie kwestii polityczności w imię zasady neutralności. Po drugie, odpowiedzialność wykonawcy roli sprowadza się do działania zgodnego z zastanymi regułami postępowania, które wyznaczają prawidłowy sposób zachowania się. Po trzecie, podstawowym celem prawa pozostaje sprawiedliwość formalna ${ }^{32}$.

Model autonomiczny budowany jest w odpowiedzi na model represyjny. Broni on odrębności prawniczego subświata od innych praktyk społecznych ${ }^{33}$. Krok ten

30 P. Nonet, P. Selznick, Law and Society in Transition. Toward Responsive Law, New York-Hagerstown-San Francisco-London 1978, s. 74-76. W tym fragmencie artykułu korzystamy z ustaleń przedstawionych przez P. Kaczmarka w pracy: Tożsamość prawnika jako wykonawcy roli zawodowej, Warszawa 2014, s. 48-53.

31 P. Nonet, P. Selznick, op. cit., s. 14-15. Zob. także E. Kustra, Rozwojowy model tworzenia prawa, „Acta Universitatis Nicolai Copernici. Nauki Humanistyczno-Społeczne" 1996, z. 307.

32 P. Nonet, P. Selznick, op. cit., s. 83.

33 Ibidem, s. 76. 
uzasadniany jest argumentem z tezy o autonomii prawa. Tezę tę pozyskuje się, odnosząc kwestię autonomii prawa wobec moralności oraz polityki ${ }^{34}$. Atutem obu wyróżnionych ujęć autonomii prawa jest możliwość przedstawiania praktyki instytucjonalnej jako struktury w pewien sposób niezależnej:

1) od działań politycznych, które ujmują prawo jako mechanizm inżynierii społecznej, za pomocą którego można tworzyć rzeczywistość społeczną,

2) od moralności społecznej czy też charakteru człowieka działającego w instytucji, co służy m.in. odparciu zarzutu o brak obiektywności prawa i subiektywizacji jako czynnika mającego wpływ na podjętą decyzję $e^{35}$.

Relacje między modelem represyjnym a autonomicznym P. Nonet i P. Selznick tak wyjaśniają:

Charakterystyczną cechą prawa represyjnego jest pasywna, oportunistyczna adaptacja instytucji prawnych do społecznego i politycznego środowiska. Prawo autonomiczne jest reakcją przeciw bezkrytycznej otwartości. Jego dominującym celem jest zachowanie instytucjonalnej integralności. W tym celu prawo impregnuje się, zawęża zakres swojej odpowiedzialności i przyjmuje ślepy formalizm za cenę integralności ${ }^{36}$.

O ile zatem model autonomiczny stanowi odpowiedź na "bolączki” modelu represyjnego, o tyle model responsywny odpowiada na pewne niedostatki modelu autonomicznego ${ }^{37}$. Posłużenie się określeniem „responsywny” autorzy tłumaczą w następujący sposób: „określamy jako responsywny, a nie otwarty czy zdolny do adaptacji, by zaznaczyć jego zdolność do odpowiedzialnej i tym samym krytycznej i wybiórczej adaptacji" ${ }^{\prime 38}$. Wskazana definicja budowana jest w opozycji do ujęcia autonomicznego, dla którego instytucje prawne mają zachować niezależność wobec innych praktyk społecznych.

Model responsywny można przedstawić za pomocą następujących cech. Po pierwsze, instytucje prawne powinny być otwarte na fakty i zmiany społeczne. $\mathrm{Z}$ tego też powodu podkreśla się refleksyjność prawniczych instytucji, których

34 W. Gromski, Autonomia i instrumentalny charakter prawa, Wrocław 2000, s. 22-29.

35 P. Selznick, The Moral Commonwealth: Social Theory and the Promise of Community, Berkeley-Los Angeles-London 1992, s. 464.

36 P. Nonet, P. Selznick, op. cit., s. 76-77.

37 Ibidem, s. 78.

38 Ibidem, s. 77. 
celem jest odpowiadanie na zmiany społeczno-prawne ${ }^{39}$. Po drugie, wskazane otwarcie powoduje, że działalność prawnika staje się zaangażowana etycznie i politycznie ${ }^{40}$. Tezę tę można odczytać jako wyraz uznania, że instytucje prawne rezygnując z zasady neutralności mają stać się bardziej dynamicznym instrumentem społecznej zmiany. $Z$ tego też powodu działalność prawnika wyznacza pojęcie aktywizmu, poznawczych kompetencji. Inaczej jednak aniżeli w modelu represyjnym, praktyka prawnicza pozostaje tutaj w możliwym konflikcie wobec praktyki politycznej. Po trzecie, celem działalności prawniczej staje się nie tylko realizacja sprawiedliwości formalnej, ale i materialnej. Responsywny model zakłada, że praktyka instytucjonalna ma odpowiadać na zmiany społeczne i próbować zapewnić sprawiedliwość $\mathrm{w}$ znaczeniu formalnym i materialnym ${ }^{41}$.

Responsywny model prawa charakteryzuje również zwiększenie siły autorytetu celu, w rozumowaniach prawniczych, kosztem autorytetu regu ${ }^{42}$. O ile preferencja reguł zakłada logocentryczny obraz rzeczywistości społecznej, którą prawo reguluje, o tyle zwrot w stronę celowości wydaje się efektem uznania, że praktyka społeczna nie jest homogeniczna. Założenie o sytuacji konfliktu i konieczności sytuacyjnego ważenia wartości zakłada możliwość poddania krytyce obowiązków prawnych. Przejawem tego jest odchodzenie w modelu responsywnym od bezwzględnego posłuszeństwa wobec prawa na rzecz moralnej odpowiedzialności za prawo. Zapobiec ma to ucieczce $w$ formalizm, chowaniu się za regułą i na jej podstawie racjonalizacji podejmowanej decyzji ${ }^{43}$. $\mathrm{Z}$ tego też powodu $\mathrm{w}$ modelu responsywnym wszelkie postacie rozmywania się władzy przez przerzucanie jej na grupę osób albo bezosobowe struktury ocenia się w sposób negatywny jako możliwe źródło niebezpiecznej tyranii czy też niesprawiedliwości ${ }^{44}$.

W świetle przedstawionych ustaleń możemy powiedzieć, że model responsywny pozostaje w opozycji do modelu autonomicznego ${ }^{45}$. $Z$ kolei model autonomiczny, jak przedstawialiśmy wyżej, stanowi odpowiedź na sprowadzenie prawa do roli instrumentu w rękach władzy politycznej. Odejście od modelu represyjnego w stronę modelu autonomicznego miało zapewnić względną niezależność prawa wobec praktyki politycznej. Wyrazem zakładanego rozdziału jest postulat sepa-

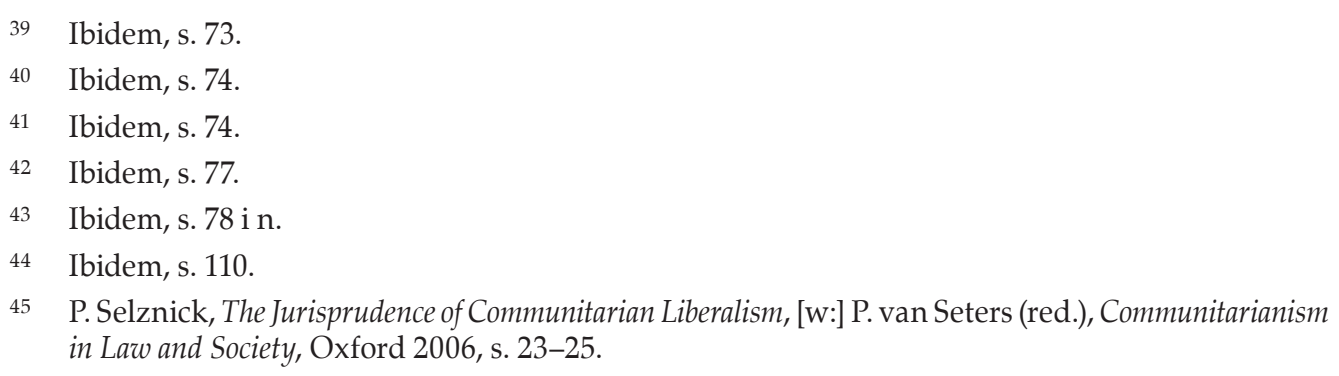


racji prawa od polityki. Doprowadził on jednak do marginalizacji sfery polityczności w działalności prawniczej w imię rządów prawa, mających na celu ograniczenie samowoli ośrodków politycznych oraz zapewnienie bezpieczeństwa prawnego obywatelom. Ceną za to było popadnięcie w formalizm, pełne posłuszeństwo prawnika wobec reguł. Z kolei model responsywny dąży do „odformalizowania” prawa. Przejawem tego jest mówienie o „osobie w roli”, co ma podkreślać, że, przyjmując rolę, stając się jej wykonawcą, nie gubi się jednocześnie wymiaru podmiotowego. W oglądzie tym konieczne jest budowanie instytucji otwartych, w których uczestniczenie sprowadza się do dialektycznego łączenia wymiaru instytucjonalnego z indywidualnym osądem nad sposobem działania.

Czy zaprezentowane trzy modele budowania instytucji prawnych można odnieść do przedstawionych wyżej ujęć edukacji? Hipotezę o korespondencji uwiarygodnia możliwość spojrzenia na omawiane projekty w świetle dwóch dylematów dotyczących budowania instytucji. Przypomnijmy, pierwszy z nich dotyczy pozycji jednostki w strukturze instytucjonalnej, a dokładniej napięcia między sprawstwem podmiotowym a strukturalnym. Z kolei drugi dylemat dotyczy napięcia między konsensem a konfliktem w przedstawianiu obrazu praktyki społecznej.

Autonomiczny model budowania instytucji zakłada separację prawa wobec innych subświatów instytucjonalnych. Przyjmuje w tym zakresie logocentryczny obraz rzeczywistości społecznej, w której poszczególne praktyki społeczne mają charakter autonomiczny. Z kolei działanie prawnika wyznaczane jest w znacznym stopniu przez zewnętrzne względem niego czynniki społeczno-instytucjonalne. Taki sposób rozstrzygania interesujących nas dylematów teoretycznych koresponduje z wizją edukacji, którą rekomenduje model strukturalno-funkcjonalistyczny. Argument z profesjonalizacji, społecznego podziału pracy jest obecny w obu dyskursach. Podobnej korespondencji można poszukiwać w relacjach między responsywnym modelem prawa a interpretatywnym ujęciem edukacji. Model responsywny przedstawia prawnika jako osobę odpowiadającą za podejmowane decyzje. Niemniej jednak jego działalność podejmowana jest w granicach wyznaczanych przez świat instytucji. Wskazany dualizm jest bliski rozstrzygnięciom proponowanym przez interpretatywny model edukacji. Źródeł wskazanej korespondencji można upatrywać w opozycyjności, odpowiednio, modelu responsywnego i autonomicznego oraz interpretatywnej i strukturalno-funkcjonalistycznej wizji edukacji. Takiego bezpośredniego przełożenia nie ma między modelem represyjnym a ujęciem konfliktowym. Nie oznacza to jednak, że poszukiwanie miejsc wspólnych dla nich nie jest możliwe. Konfliktowe ujęcie edukacji czy też nawiązujące do niego podejście krytyczne można przedstawiać jako problematyzację rozstrzygnięć rekomendowanych przez represyjny model prawa. Ekspozycja pojęcia refleksyjności, odpowiedzialności w procesie kształcenia wyraźnie prze- 
ciwstawia się wizji wychowanka instytucji, jaką możemy zrekonstruować z modelu represyjnego.

Zaprezentowane trzy modele: represyjny, autonomiczny i responsywny można przedstawiać $\mathrm{w}$ świetle pytania o sposób budowania instytucji prawno-administracyjnych, co staraliśmy się wyżej wykazać. Wymienione modele są jednak przede wszystkim rozpatrywane jako ilustrujące rozwój prawa. W modelu represyjnym zakłada się idealizacyjne podporządkowanie prawa - praktyce politycznej w państwie. Takie ujęcie koresponduje z koncepcjami państwa i porządku prawnego Carla Schmitta ${ }^{46}$. Model autonomiczny, budowany na założeniu o separacji prawa wobec świata polityki przypisuje prawu funkcję stabilizacyjną za cenę zachowania neutralności. Jego odpowiednikiem byłaby koncepcje państwa prawa nawiązujące do pozytywizmu prawniczego ${ }^{47}$. Z kolei w idealizacji modelu responsywnego, jak odnotowuje Ewa Kustra, „zmianie ulega koncepcja podmiotu i przedmiotu oddziaływań prawa" ${ }^{\prime \prime 8}$. Zmiana ta, polegająca na podkreśleniu pojęcia interakcji w procesie oddziaływań między podmiotem a strukturą, kieruje nas w stronę pragmatyczno-hermeneutycznej koncepcji prawa.

\section{Nurty konstytucjonalizmu i ich dydaktyczne konsekwencje}

\section{Problem dydaktyki prawa konstytucyjnego}

Pogląd, że konstytucja jest podstawą porządku prawnego - albo przynajmniej zajmuje w tym porządku miejsce szczególne - uznać można za powszechny, a nawet oczywisty. Same konstytucje, przynajmniej tzw. konstytucje pisane, zazwyczaj to deklarują (jak chociażby ma to miejsce w art. 8 ust. 1 Konstytucji polskiej). Kiedy jednak spojrzymy na dydaktykę akademicką realizowaną na polskich wydziałach prawa, to sprawa nie wydaje się już tak oczywista. W programach studiów prawniczych wiedza o konstytucji, wpleciona w rozbudowany program kilkudziesięciu wykładanych przedmiotów, gubi swój szczególny charakter, czyniąc prawo konstytucyjne jednym $z$ wielu etapów na długiej drodze do uzyskania statusu dyplomowanego prawnika. Funkcja tego przedmiotu w programach nauczania bywa dość niejasna. Czy mamy tu do czynienia z przedmiotem ogólnym, tylko wprowadza-

\footnotetext{
46 E. Kustra, op. cit., s. 8.

47 Ibidem, s. 9; J. Srokosz, Komunitariańska wizja prawa responsywnego a koncepcja państwa prawa, [w:] M. Andruszkiewicz, A. Breczko, S. Oliwniak (red.), Filozoficzne i teoretyczne zagadnienia demokratycznego państwa prawa, Białystok 2015, s. 144.
}

48

E. Kustra, op. cit., s. 9. 
jącym w program specjalistycznego przygotowania studenta na dalszych semestrach studiów (obok Wstępu do prawoznawstwa, Logiki prawniczej czy przedmiotów historycznych), czy też z dyscypliną, posiadającą „"własny tekst”, a zatem taką, która pozwala uprawiać i dydaktycznie upowszechniać metodykę pracy zbliżoną do dogmatyki prawa. Na pierwszą alternatywę (propedeutyka wiedzy o prawie) w polskich uwarunkowaniach trudno byłoby się zgodzić zarówno teoretykom prawa, jak i samym konstytucjonalistom. Konstytucja i doktryna prawa konstytucyjnego nie dostarczają chociażby aspirującego do uniwersalności zasobu pojęć oraz zbudowanych na ich podstawie reguł dyskursu prawniczego porównywalnego do wiedzy analitycznej udostępnianej przez Logikę czy Wstęp. Przeciwnie, sytuuje to raczej wiedzę z prawa konstytucyjnego $\mathrm{w}$ roli jednego $\mathrm{z}$ wielu - obok standardowych dogmatyk prawa - obszarów argumentacyjnej aplikacji tego rodzaju ogólnych przedmiotów nauczania. Dla badacza uprawiającego analityczną teorię prawa i referującego jej dorobek przy okazji wykładu ze Wstępu do prawoznawstwa pojęcia konstytucyjne zasadniczo, przynajmniej od strony swojej konstrukcji, nie różnią się od takich samych pojęć pojawiających się w innych dyscyplinach prawniczych.

Jako rozsądna może być zatem traktowana tylko druga alternatywa: nauka i nauczanie prawa konstytucyjnego, to wiedza i dydaktyka limitowana przedmiotowo tekstem konstytucji oraz pewną grupą okołokonstytucyjnych ustaw, aktów prawa międzynarodowego, europejskiego etc. W tej perspektywie prawo konstytucyjne to po prostu gałąź prawa i nadbudowana nad nią, wyspecjalizowana naukowo i dydaktycznie dyscyplina prawnicza. Nauka prawa konstytucyjnego - w tej perspektywie - staje się nauką szczegółową prawoznawstwa, albo wręcz dogmatyką ukształtowaną na pewnym zbiorze tekstów, z konstytucją na czele. Stanowiska takiego zasadniczo nie zmieniają obecne w doktrynie prawa konstytucyjnego rozważania o autonomii pojęć konstytucyjnych, o szczególnej roli zasad konstytucyjnych czy o specyfice wykładni tekstu konstytucji ${ }^{49}$. Tego rodzaju „lokalne teorie" obecne są przecież - zapewne w mniejszym stopniu aniżeli ma to miejsce w odniesieniu do konstytucji - również w innych szczegółowych naukach prawa, nieaspirujących do jakiejś szczególnej wyjątkowości (np. w doktrynie prawa administracyjnego czy publicznego prawa gospodarczego ${ }^{50}$ ). Ten kierunek budowania

49 Zob. np. S. Wronkowska, O niektórych osobliwościach konstytucji i jej interpretacji, [w:] M. Smolak (red.), Wyktadnia konstytucji. Aktualne problemy i tendencje, Warszawa 2016, s. 15 i n.; J. Trzciński, Znaczenie autonomicznej wykładni konstytucji na przykładzie orzecznictwa sądów administracyjnych, [w:] ibidem, s. 55 i n.; T. Stawecki, Koncepcja autonomicznej wykładni pojęć konstytucyjnych: od praktyki do teorii, [w:] T. Stawecki, J. Winczorek (red.), Wyktadnia konstytucji. Inspiracje, teorie, argumenty, Warszawa 2014.

50 W. Jakimowicz, Wykładnia w prawie administracyjnym, Zakamycze 2006, s. 182 i n.; E. Kosieradzka, Odrębności procesu interpretacyjnego publicznego prawa gospodarczego (ze szczególnym uwzględnieniem 
dorobku nauki prawa konstytucyjnego, choć, jak można sądzić, najbardziej chyba popularny w środowisku prawniczym, nie oddaje wyjątkowej roli konstytucji normatywnie artykułowanej w samej ustawie zasadniczej. Może tylko potwierdzać tezę o (względnej) autonomii konstytucji, a nie o jej wyjątkowości.

Jest jeszcze możliwa trzecia droga. Dostrzegamy ją w wiedzy ogólnej, przede wszystkim tej z obszaru filozofii polityki i filozofii prawa. Jej ślady pojawiają się również w dydaktyce prawniczej. Przy okazji zajęć fakultatywnych, seminariów czy wykładów z prawniczo zorientowanej filozofii student prawa dowiaduje się również czegoś o zróżnicowaniu samych koncepcji konstytucji, o rozbieżnych nurtach konstytucjonalizmu, o sporach toczonych wokół wykładni konstytucji. Tego rodzaju, otwarte na refleksję filozoficzną ujęcie problematyki prawno-konstytucyjnej - co zrozumiałe - znajduje słaby wyraz w zawodowych umiejętnościach absolwentów polskich wydziałów prawa, a tym samym w niewielkim stopniu obecne jest $\mathrm{w}$ rodzimej debacie publicznej. A niewątpliwie bardzo by się adwersarzom tego sporu przydał. W tej sekwencji naszego artykułu chcemy rozważyć właśnie tę trzecią drogę i pokazać, że konstytucję i - nielimitowaną gałęziowymi dystynkcjami - wiedzę o konstytucji można „potraktować poważnie”, tj. w sposób korespondujący z przekonaniem, że konstytucja naprawdę jest „najwyższym prawem Rzeczpospolitej Polskiej".

Przywołane w tej części artykułu trzy koncepcje (filozofie) konstytucji - oczywiście, ze względu na rozmiary i potrzeby niniejszego tekstu, przywołane tylko fragmentarycznie - prowadzą nas wniosku, że nie każdy sposób teoretyzowania czy filozofowania o konstytucji stwarza równie atrakcyjną podstawę dla budowania dydaktyki akademickie. Jedne z nich (H. Kelsen) powodują swoiste "rozmycie” się wiedzy i dydaktyki z prawa konstytucyjnego w szerokim spectrum problemów nauki prawa, inne (C. Schmitt) eliminują, bądź spychają na margines, potrzebę prawniczego znawstwa materii konstytucyjnej, a jeszcze inne (doktryna judicial review) zdają się właśnie otwierać - przynajmniej patrząc na problem z polskiej perspektywy - bardzo obiecującą przestrzeń dla rewaluacji nauki i praktyki (a więc i dydaktyki) konstytucyjnoprawnej.

W poprzednich fragmentach niniejszego tekstu przywołane zostały trzy „socjologie dydaktyki" (ujęcie strukturalno-funkcjonalne, konfliktowe i interpretatywne), które następnie powiązane zostały z "trzema modelami instytucji prawnych" autorstwa F. Noneta i F. Selznicka. Sądzimy, że koincydencje te dają się kontynuować (aplikować) na grunt obecnych w literaturze teoretyczno- i filozoficzno-prawnej, koncepcji pojmowania prawnej funkcji konstytucji (tzw. modeli kontroli

fazy walidacyjnej), [w:] L. Leszczyński (red.), Wykładnia prawa. Odrębności w wybranych gatęziach prawa, Lublin 2006, s. 33 i n. 
konstytucyjności ${ }^{51}$ ), a istotnych również z punktu widzenia tego, jak postrzegana jest (może być) w prawniczej dydaktyce akademickiej wiedza o konstytucji i dorobek współczesnego konstytucjonalizmu. Kontynuując triadyczny schemat argumentacji sądzimy, że ujęcie strukturalno-funkcjonalne dydaktyki, wraz z autonomicznym wariantem instytucji prawnych, daje się odnieść do Kelsenowskiego modelem kontroli konstytucyjności prawa; wariant konfliktowy dydaktyki oraz koncept prawa represywnego daje się łączyć z ideą porządku konstytucyjnego zbliżoną do stanowiska C. Schmitta, wreszcie krytyczny (bazujący na ujęciu interpretatywnym) wariant edukacji oraz responsywne ujęcie instytucji prawnych może służyć za socjologiczne ugruntowanie dla tzw. rozproszonej kontroli konstytucyjności prawa, modelowo realizowane w amerykańskim judicial review.

\section{Wiedza o konstytucji. Hans Kelsen}

Zacznijmy od wariantu Kelsenowskiego, ponieważ, po pierwsze, to on właśnie najczęściej identyfikowany jest z kontynentalną (w tym również polską) praktyką prawno-konstytucyjną ${ }^{52}$, a po drugie - jak wiemy już z poprzednich rozważań o dydaktyce ujmowanej na sposób strukturalno-funkcjonalny oraz o autonomizacji instytucji - to przede wszystkim na krytyce tych właśnie stanowisk budowane są podejścia konkurencyjne. W doktrynie prawa konstytucyjnego podobną rolę zdają się spełniać poglądy H. Kelsena dotyczące miejsca i roli ustawy zasadniczej w porządku prawnym ${ }^{53}$.

Stanowisko H. Kelsena - jeśli ograniczmy się do jego dorobku z najbardziej reprezentatywnego okresu ${ }^{54}$ - wydaje się być klarowne: prawo jest systemem opartym na hierarchicznej strukturze, jest zbiorem odpowiednio uporządkowanych przez naukę prawa ${ }^{55}$ norm posiadających wspólną podstawę obowiązywania. System prawa, to oparta na upoważnieniu (delegacji), konstrukcyjnie u swego szczytu spięta konceptem tzw. normy podstawowej, logiczna jedność norm. Jedności tej

51 Zob. M. Korycka-Zirk, Filozoficznoprawny wymiar kontroli konstytucyjności, Torun 2017. Na tej też pracy opieramy wykorzystaną w niniejszym artykule triadyczne systematykę kontroli konstytucyjności prawa.

52 Zob. A. Kustra, Kelsenowski model kontroli konstytucyjności prawa a integracja europejska. Studium wptywu, Torun 2015. Autorka we wstępie do pracy przedstawia "mapę” państw europejskich zdominowanych przez model Kelsenowski, a także przypadki porządków prawnych zorientowanych na ujęcia konkurencyjne.

53 Zob. np. A. Sulikowski, Wspótczesny paradygmat sądownictwa konstytucyjnego wobec kryzysu nowoczesności, Wrocław 2008, s. 40 i n.

54 M. Zalewska, Problem zarachowania w normatywizmie Hansa Kelsena, "Jurysprudencja” 2014, 1, s. 46.

55 J. Wróblewski, Krytyka normatywistycznej teorii prawa i państwa Hansa Kelsena, Warszawa 1955, s. 32. 
w wymiarze praktycznym, a w imię logicznego postulatu zupełności i niesprzeczności systemu, służyć ma konstytucyjna kontrola prawa aktów prawnych niżej usytuowanych $\mathrm{w}$ hierarchii systemu. Wyspecjalizowany sąd konstytucyjny staje się w ten sposób „strażnikiem konstytucji”, a zarazem „strażnik systemu”. „Konstytucja spaja system prawny i jednocześnie go kreuje, [jednak] nie treściowo, lecz strukturalnie" ${ }^{\prime 56}$. Podobnie rzecz się ma z rolą przypisywaną sędziemu konstytucyjnemu. To norma kompetencyjna nadaje mu ",autorytet" - tytuł do podejmowania działań kontrolnych. Szczególna rola sędziego konstytucyjnego nie jest więc legitymizowana jego powiązaniem z suwerenem, lecz normatywnym następstwem przyznanej przez konstytucję szczególnej kompetencji prawnej. Specjalizacja sędziowska ma zatem podwójny wymiar: (a) przedmiotowy - sąd konstytucyjny jest „sądem prawa” zapewniającym spójność i zupełność systemu, a nie zarządcą umocowanym do kierowania się jakimikolwiek racjami pozaprawnymi (moralnymi, gospodarczymi czy politycznymi) oraz (b) podmiotowy - sąd konstytucyjny jest sądem eksperckim, w którego składach zasiadać powinni profesjonalni sędziowie, biegli w mechanizmach stosowania i wykładni prawa. Mechanizmy te mają być jednolite dla całego systemu, a więc takie same dla wykładni konstytucji i zwykłych ustaw ${ }^{57}$.

Zamiarem Kelsena było stworzenie takiej teorii prawa, która czyni zadość warunkom uznania jej za naukową, czyli przede wszystkim zdolną do spełniania wymogu ogólności i jednoznaczności ${ }^{58}$. Najlepiej do tego nadawała się tradycyjna logika, fundująca uniwersalną i neutralną aksjologicznie wiedzę prawniczą. Oznaczało to preferencję dla analitycznej teorii prawa w jej przede wszystkim strukturalnym (syntaktycznym) wariancie, a pierwszym jej obiektem badawczym, uznawanym za niezbędny dla zrozumienia całej konstrukcji systemu prawa, było pojęcie normy prawnej ${ }^{59}$. Poszukiwanie tzw. idealnej formy (schematu) normy prawnej najlepiej chyba oddaje sens znanego stwierdzenia Kelsena, że „nauką o istocie prawa jest nauka o normie prawnej". Takie podejście do roli i zadań nauki mocno ugruntowuje autonomię prawoznawstwa wobec zewnętrznego (społecznego i naukowego) otoczenia ${ }^{60}$. Nauczanie akademickie według "czystej nauki o prawie” nie jest nauczaniem prawa pozytywnego (stanowionego), bo to ma zmienną treść,

56 M. Korycka-Zirk, op. cit., s. 44 i 46.

57 Zob. A. Sulikowski, op. cit., s. 41.

58 M. Zalewska, Problem zarachowania..., s. 40.

59 J. Wróblewski, op. cit., s. 129.

60 „Mówienie o nauce prawa jako autonomicznej wobec innych nauk (...) było nadrzędnym celem Kelsena” - M. Zalewska, Czy pragmatyka jest u Kelsena możliwa?, „Filozofia Publiczna i Edukacja Demokratyczna" 2013, 2(2), s. 180. 
ad hoc uzależnioną od aktualnego prawodawcy uwikłanego w bieżącą politykę. Jest natomiast nauczaniem uniwersalnych pojęć, poznawaniem teoretyczno-poznawczych pojęciowych narzędzi ${ }^{61}$, które pozwalają nabyte m.in. w drodze edukacji, aprioryczne kategorie prawnicze odnosić do empirycznego materiału prawnego, czyli do poszczególnych tekstów ${ }^{62}$. Kelsenowska teoria prawa jest zatem ostatecznie teorią prawa pozytywnego ${ }^{63}$ - prawa wymuszającego ze względów praktycznych przedmiotową, gałęziową specjalizację. Jednak jest to specjalizacja dyktowana potrzebami organizacyjnego ogarnięcia złożonej rzeczywistości prawnej (wielości tekstów prawa pozytywnego). Natomiast służące poznawaniu prawa pozytywnego „pojęcia prawne są [już] tworzone tylko przez jurysprudencję, która ze względu na swój formalny charakter może być nazwana geometriq zjawiska prawnego"64.

Konstytucja, choć zajmuje szczególne miejsce w hierarchii systemu prawa, nie jest tu wyjątkiem. Mówienie w odniesieniu do niej o autonomii pojęciowej lub interpretacyjnej łamałoby bowiem formalno-logiczny, uniwersalny charakter prawniczych konstrukcji pojęciowych czystej teorii prawa. Konstytucja („,konstytucja w znaczeniu prawno-logicznym ${ }^{\prime \prime 5}$ ) jest również tylko uzasadnieniem i gwarantem logicznej spójności systemu. A jeżeli tak, to również „sąd konstytucyjny funkcjonuje [tylko] "na swoim odcinku", nie zarządza globalnie, choć jest niezbędny dla funkcjonowania całości systemu (...). Kontrola konstytucyjności prawa jest bowiem „przedsięwzięciem technicznym" w systemie norm, zapewniającym tworzenie prawa w odpowiednim stopniu spójnego"66.

W Kelsenowskim obrazie nauki prawa mamy zatem do czynienia z konieczną, choć tylko techniczno-praktyczną specjalizacją na poziomie poszczególnych dogmatyk prawa - w tym również dogmatyki prawa konstytucyjnego - i uniwersalną, pojęciową jurysprudencją teoretycznej nauki o prawie. Odpowiednio do tego, w wymiarze prawniczej dydaktyki akademickiej, pojawi się nam potrzeba poznawania uniwersalnych form poznawania prawniczego, a więc dydaktyki promującej przede wszystkim nauczanie prawniczych zastosowań logiki (Logika prawnicza) oraz upowszechnianie pojęciowego dorobku jurysprudencji analitycznej (Wstęp

61 Kategorią „pojęć-narzędzi” prawniczego poznania posługiwał się F. Longchamps - zob. idem, O używaniu pojęć w naukach prawnych, Zeszyty Naukowe Uniwersytetu Wrocławskiego, Prawo VII, Wrocław 1960.

62 A. Peretiatkowicz, Teoria prawa i państwa H. Kelsena, „Ruch Prawniczy, Ekonomiczny i Socjologiczny" 1937, 17(4), s. 454.

63 Por. H. Kelsen, Reine Rechtslehre, 1934, przedruk: Tübingen 2008, s. 38.

64 Idem, Haupteprobleme der Staatsrechtslehre: entwickelt aus der Lehre vom Rechtssatze, Aalen 1984, s. 91.

65 A. Peretiatkowicz, op. cit., s. 463.

66 A. Sulikowski, op. cit., s. 42-43. 
do prawoznawstwa). Poszczególne dogmatyki prawnicze będą, stosownie do własnych potrzeb, na swoich przedmiotowych domenach badawczych, ten ogólny dorobek aplikować i rozwijać, jednak w taki sposób, który nie burzy logicznej struktury całości (systemu prawa, spójności form poznania prawniczego). Dydaktyka dogmatycznoprawna będzie tu swoistym testowaniem na wybranych fragmentach prawa pozytywnego owych uniwersalnych form - pod czujnym okiem teorii prawa. Kolejnym krokiem w procesie przybliżania nauki do rzeczywistości prawnej („pozytywizacji” teorii) będą aplikacje prawnicze, aż po ostateczną konfrontację na sali sądowej. Nauka jest zatem, podobnie jak pojęciowy obraz systemu prawa, pewną hierarchiczną strukturą, która narzuca jednostce określone miejsce i rolę $w$ jej obrębie. W ramach tak skonstruowanej strategii uprawiania nauki prawa i kształcenia akademickiego nie da się budować edukacji konstytucyjnej odpowiadającej szczególnej pozycji konstytucji w porządku prawnym. Relacje władzy i wiedzy mają co prawda podobnie hierarchiczny charakter, ale to ta druga narzuca porządek myślenia prawniczego.

Z perspektywy Kelsena wartością kierująca nauką i nauczaniem prawa będzie dążenie do pewności rozstrzygnięć prawnych, dających jednostce poczucie bezpieczeństwa w konfrontacji z państwem i innymi uczestnikami obrotu prawnego (ujęta formalnie zasada państwa prawa, sprawiedliwość formalna, zamknięty system prawa, sylogistyczny model decyzji sądowej), kosztem responsywnej, dyskursywnej otwartości na społeczne wyzwania, w tym również na tzw. trudne przypadki orzecznicze. Sprzyjać to będzie kształtowaniu sylwetki apolitycznego prawnika-eksperta, wyposażonego bądź to w analityczna wiedzę ogólną i zdolnego do pieczy nad „całością", bądź to specjalisty umiejącego tę ogólną wiedzę aplikować do poszczególnych dziedzin prawa. Optymalne składy osobowe sądu konstytucyjnego powinny stanowić zatem swoisty, kooperujący mikst, składający się z teoretyków, znawców „istoty prawa”, użytecznych w sprawach prawnie bardziej złożonych, i biegłych w znajomości tekstu konstytucji i innych aktów prawnych reprezentatywnych przedstawicieli szczegółowych dyscyplin prawoznawstwa, użytecznych w sytuacjach prawnie mniej skomplikowanych.

Koncepcji prawa i prawoznawstwa H. Kelsena uprawnia, naszym zdaniem zasadniczy wniosek, że to - używając terminologii strukturalistyczno-funkcjonalnej - struktura prawniczej wiedzy narzuca sposób edukacji, a w następstwie tego, również kształtuje również późniejsze społeczne role prawnika (piecza nad prawem jako systemem) oraz dostępne sposoby uzasadniania podejmowanych rozstrzygnięć (argumentacje odwołujące się do logiki). Buduje to ekspercki i apolityczny punkt wyjścia. Jednak te nabyte w procesie edukacji neutralne formy prawniczego - naukowego - poznawania konfrontować się będą w praktyce prawniczej, a w szczególności w orzecznictwie sądów konstytucyjnych, z nieuchronną poli- 
tycznością ${ }^{67}$. Polityczność prawa pojawia ujawni się zatem wtórnie jako problem przejścia od form prawa do jego treści prawa, a więc przede wszystkim w procesie prawotwórczym oraz w związku z kontrolą konstytucyjności prawa. Orzeczenia specjalnego sądu konstytucyjnego będą przecież (negatywnie) wpływać na tekstowe zasoby prawa pozytywnego. Prawnik w "strukturze władzy”, zasiadający w składach parlamentu, rządu, a także piastujący funkcje zewnętrznej kontroli prawa będzie zatem już musiał być innym prawnikiem niż ten, który zasiada na uniwersyteckiej katedrze lub który został ukształtowany pod wpływem uniwersytetu.

\section{Perspektywa Carla Schmitta}

H. Kelsena poglądy na konstytucję notoryjnie przeciwstawiane są stanowisku C. Schmitta. Relacje między władzą (władzą polityczną) i nauką prawa ulegają tu zasadniczemu odwróceniu. Łączy ich jednak radykalizm wyznawanych poglądów. H. Kelsen mawial, że "państwo jest systemem norm”. C. Schmitt natomiast twierdził, że „państwo jest konstytucją", że państwo istnieje jako coś, co już jest, tak czy inaczej, ukonstytuowane. To całkowicie odwrócone pojmowanie ontologicznego wymiaru konstytucji. C. Schmittowi nie o konstytucję w sensie prawnym w tym stwierdzeniu chodzi - pojmowaną jako zbiór reguł limitujących funkcjonowanie wspólnoty państwowej - ale o samą tę wspólnotę, realnie tu i teraz istniejącą. Państwo jest określonym stanem faktycznym, stanem jedności i porządku, a jego (państwa) konstytucja jest konkretnym życiem i indywidualną egzystencją. Mowa tu o tzw. konstytucji absolutnej. To nie państwo jest wyposażone w konstytucję, zgodnie z którą kształtowana jest wola państwowa. „Państwo bowiem samo w sobie jest już konstytucją, to znaczy jest mającym bytowy, ontologiczny charakter, stanem, stanem jedności i porządku (...)" ${ }^{\prime \prime}$. "Dla C. Schmitta nauka o konstytucji jest poznaniem głębszym i poważniejszym, a zarazem problemowo trudniejszym. Jest to nauka (...) w jej bardzo szerokim materialnym i ideowym kontekście, nie ogranicza się do badania samych prawniczych tekstów (...), jest badaniem niejako tła, zaplecza ustawy zasadniczej, badaniem tego, na czym konstytucja się opiera, czego jest odzwierciedleniem (...), świeci światłem odbitym (...)"69. Mamy oto konstytucję

67 Polityczny charakteru kontroli konstytucyjności prawa zauważa również H. Kelsen - zob. idem, Istota i rozwój sądownictwa konstytucyjnego, Warszawa 2009, s. 39. Kelsen pisał mianowicie o „funkcjonalnej" trudności „w oddzielaniu od siebie sądownictwa i ustawodawstwa". Podstawą takiego oddzielenia miało być rozróżnienie na normy generalne (domena ustawodawstwa) i indywidualne (sądownictwo). Jednak w przypadku sądów konstytucyjnych kryterium to ulega załamaniu.

68 C. Schmitt, Nauka o konstytucji, Warszawa 2013, s. 4.

69 P. Kaczorowski, Carl Schmitt, jego nauka o konstytucji i kwestie suwerena-ustrojodawcy, „Teologia Polityczna co Tydzień" - https://www.teologiapolityczna.pl/ (dostęp: 30.05.2016). 
rzeczywistą (absolutną), wyróżnianą ze względu na przedmiot (tzw. rzeczywistość konstytucyjna) oraz konstytucję pozytywną - czyli akt prawny, suwerennej, większościowej władzy decyzyjnie zdolnej do tego, aby nadać politycznej wspólnocie odpowiednią formę. Konstytucja pozytywna jest tylko „świadomą decyzją, którą jedność polityczna - poprzez sprzyjające władzę ustawodawcze - podejmuje dla siebie i którą sama sobie daje" ${ }^{\prime 70}$.

Akt konstytucyjny jest aktem tego, kto ma władzę polityczną. Władza polityczna ujawnia swoją rzeczywistą siłę w sytuacjach konfliktów. To stany wyjątkowe pokazują, kto jest realnym suwerenem w państwie, kto jest zdolny ochronić rzeczywisty porządek konstytucyjny przed kryzysami, a także skutecznie ten porządek w sensie pozytywnym wyartykułować. Nie będą to oczywiście apolityczne sądy konstytucyjne czy sądy powszechne. Odpowiedzią C. Schmitta będzie raczej „usądowienie polityki"71. Strażnikiem konstytucji będzie na przykład posiadająca polityczny mandat (wybierana bezpośrednio) głowa państwa. Prawo i konstytucja są zatem areną walki, ujawniania się opozycji wróg-przyjaciel (opozycji podkreślanej również w wielu, wydawałoby się odległych od C. Schmitta, tzw. krytycznych teoriach demokracji ${ }^{72}$ ). Deklarowana apolityczność sądów i trybunałów, ich orientacja na prawa i wolności obywatelskie czy odwoływanie się do zasady trójpodziału władzy - zdaniem autora Nauki o konstytucji - nie tylko utrudnia skuteczne rozwiązywanie konfliktów politycznych, ale również sprzyja ich ukrywaniu. Oddanie deklarowanej władzy tym, którzy ją rzeczywiście posiadają, i są w stanie skutecznie realizować, powinno prowadzić powinno do demistyfikacji tych praktyk, do przywrócenia prawa rzeczywistości, a tym samym zbliżenia konstytucji pozytywnej do konstytucji absolutnej. W języku K. Marksa oznaczałoby to likwidację "fałszywej świadomości" będącej efektem pracy (nowoczesnych, liberalnych) elit i ich uprzywilejowanej pozycji ${ }^{73}$.

Idea badania konstytucji pozytywnej poprzez ujawnianie tego, na czym „się opiera", czego jest "odzwierciedleniem” oraz czy, i na ile, adekwatnie wyraża w swoim tekście wolę faktycznego suwerena, jest dla nauki prawa, praktyki prawniczej oraz zastanego programu zawodowej edukacji prawników zasadniczą zmianą. Oznacza bowiem odebranie konstytucji jej funkcji normatywnej i prowadzi do odseparowania sądów i trybunałów od konstytucji jako podstawy orzekania. Nauczanie prawa konstytucyjnego przestaje tym samym pełnić rolę istotnego fragmentu

\footnotetext{
70 C. Schmitt, Nauka o konstytucji..., s. 54.

71 Ibidem, s. 210.

72 Zob. np. Ch. Mouffe, Paradoks demokracji, Wrocław 2005, w szczególności rozdz. 2 (Carl Schmitt i paradoks liberalnej demokracji) oraz rozdz. 4 (Agonistyczny model demokracji).

$73 \quad$ Zob. wyżej przypis 16.
} 
zawodowego przygotowania prawnika do zawodu. Pozostaje oczywiście sam tekst konstytucji, tym niemniej już jego doktrynalne techniki egzegezy, spory wokół wykładni konstytucji, debaty wokół statusu pojęć konstytucyjnych, konstytucyjnych zasad prawa czy rozważania o filozofii konstytucji zdają się tracić rację bytu. Choć pozostaje konstytucja jako pisany dokument, to zanika konstytucja jako akt prawny wraz z wszystkim tym, co ją naukowo i kulturowo obudowuje, a co składa się na dorobek tzw. konstytucjonalizmu. Oznacza to również rozbrat z odrębną, przynajmniej względnie autonomiczną edukacją prawniczą, choć oczywiście nie z edukacją w ogóle. Edukacja - jak pisaliśmy wcześniej referując tzw. konfliktowe ujęcie - staje się edukacją legitymizującą władzę, a uniwersytet, obok innych instytucji, areną walki o władzę. Dydaktyka ma pełnić funkcje jawne (udostępniać pewną wiedzę) i ukryte (dostarczać uzasadnień i podtrzymywać system produkcji i władzy), wpisując się w program społecznie legitymizowanej władzy. Empiryczna socjologia, odsłaniająca tzw. polityczność (konfliktowy charakter współczesnej demokracji) ${ }^{74}$, filozofia polityki, historia doktryn politycznych i prawnych (nauka o ustrojach), teologia (metafizyka), a może i psychologia społeczna powinny urastać do pozycji dziedzin nauki, którym po drodze będzie z nauczaniem prawa konstytucyjnego ${ }^{75}$. Idea aplikacji prawniczych w obecnym kształcie programowym i organizacyjnym wydaje się również niemożliwa do utrzymania, a właściwie zbędna. I w tym przypadku pomysł budowania edukacji wokół wiedzy konstytucji byłby, oględnie mówiąc, raczej trudny do realizacji. Chyba, że byłaby to konstytucja absolutna, ale wtedy - ze względu holistyczny charakter wiedzy o tak rozumianej konstytucji ${ }^{76}$ - wątpliwym byłoby sens prowadzenia dydaktyki o konstytucji właśnie na wydziałach prawa.

74 Por. C. Schmitt, Pojęcie polityczności, [w:] idem, Teologia polityczna i inne pisma, Warszawa-Kraków 2000, s. 31 i n.; L. Koczanowicz, Antagonizm, agonizm i radykalna demokracja. Koncepcja polityki Chantal Mouffe, [w:] Ch. Mouffe, op. cit., s. 7 i n.

75 Starszemu pokoleniu badaczy konstytucji i dawnym studentom przedmiotu „Polskie prawo państwowe" - bo nieprzypadkowo tak ten przedmiot na wielu uczelniach był nazywany jeszcze w latach 70. - ten kierunek myślenia przywodzi na myśl debatę wokół normatywnego versus ideologicznego charakteru konstytucji (zob. S. Rozmaryn, Konstytucja jako ustawa zasadnicza Polskiej Rzeczpospolitej Ludowej, Warszawa 1961). Liczący się, a nawet dominujący nurt ówczesnych znawców Konstytucji PRL (choć już nie sam Rozmaryn w przywołanej pracy) był zwolennikiem poglądu, że konstytucje można traktować, przynajmniej w sporych jej fragmentach, jako „rejestrację osiągnięć" („osiągniętego etapu w budowie socjalizmu”), mówiło się też o „konstytucji bilansu” etc. Krytycznie o tego ideologicznie pozycjonowanej konstytucji pisze J. Trzciński, Konstytucja PRL a konstytucjonalizm socjalistyczny, [w:] K. Działocha (red.), Konstytucja PRL po 30 latach jej obowiqzywania, Wrocław 1985, s. 44. Konsekwencją takiego ujęcia był np. również pogląd (S. Rozmaryn, J. Beer), że „w razie sprzeczności ustawy z Konstytucją stosuje się ustawę, ponieważ Konstytucja nic przeciwnego nie stwierdza" - zob. J. Trzciński, Konstytucja PRL..., s. 45.

76 We wprowadzeniu do książki Ł. Święcickiego, Carl Schmitt i Leo Strauss. Krytyka pozytywizmu prawniczego w niemieckiej myśli politycznej czytamy, że „łączy ich holistyczne podejście do rzeczy- 


\section{Doktryna Judicial Review}

Koncepcja tzw. rozproszonej kontroli konstytucyjności prawa wydaje się być wobec wykluczającej alternatywy Kelsen-Schmitt rozsądną odpowiedzią. Amerykańska judicial review u swoich teoretyczno-filozoficznych podstaw zawiera bowiem - z jednej strony - bliskie Schmittowi założenie o substancjalnym uzasadnieniu bytu konstytucji. Jest bowiem w tradycji amerykańskiej konstytucja wyrazem woli suwerennego ludu pojmowanego jako wspólnota polityczna. „W tradycyjnym konstytucjonalizmie amerykańskim traktuje się konstytucję jako ostateczny wyraz woli społeczeństwa politycznego - suwerena (...)" ${ }^{\prime 77}$. Jednak z drugiej strony - i tu kończą się już analogie z C. Schmittem - polityczna wola staje się zarazem kryterium kontroli władzy sprawowanej na jej podstawie, co wymaga przyobleczenia tej woli w odpowiednie formy prawne. Porządek ujęty w postać instytucji prawnych, wraz z zasadą supremacji konstytucji, ma służyć kontroli władzy i ochronie równych praw jednostek. Jak pisze M. Korycka-Zirk, „zasada zgody społecznej oznacza supremacje ludu, ale zarazem supremację prawa"78. Już tylko powierzchowny związek z poglądami autora Nauki o konstytucji ma obecna w doktrynie amerykańskiej (a znana także innym doktrynom, np. francuskiej) koncepcja istnienia dwóch konstytucji: pisanej i niepisanej. Ta druga bowiem uzupełniać ma pierwszą w oparciu o dorobek konstytucjonalizmu, przy zasadniczym udziale orzecznictwa powstającego w związku z powszechną, sądową kontrolą konstytucyjności (judicial review) $)^{79}$.

Idąc tą drogą, zbliżamy się w pewien sposób do poglądów H. Kelsena na prawną funkcję konstytucji i rolę prawników (nauki, doktryny) w jej kształtowaniu (pamiętając oczywiście o tej zasadniczej różnicy, że to sądowa kontrola rozproszona i jej konceptualizacje ujęte w dorobku konstytucjonalizmu zastępować będą Kelsenowską wizję scentralizowanej kontroli in abstracto). Oba nurty przywracają jednak - w zestawieniu z C. Schmittem - wagę argumentacji prawniczej, a tym samym ukazują znaczenie nauki prawa, jej przynajmniej względną autonomię wobec otoczenia społecznego (w przy padku judicial review), a w konsekwencji przywracają również wagę edukacji prawniczej wspartej na dorobku nauki. Jednak

wistości i prymarne założenie o politycznej naturze człowieka, które stanowią punkt wyjścia ich dalszej refleksji. Ta refleksja (...) dotyczy podstaw porządku politycznego i prawa".

77 M. Korycka-Zirk, op. cit., s. 51.

78 Ibidem, s. 49.

79 Zob. A.R. Amar, American Constitutionalism - Written, Unwritten and Living, "Harvard Law Review” 2013, 126, s. 195 i n. 
prawoznawstwo i edukacja prawnicza w każdym z tych podejść do konstytucji i konstytucjonalizmu nakierowane będą na odmienne cele i wartości.

Jeżeli w przypadku koncepcji Kelsena zasadniczą wartością jest pewność prawa, wraz z obrazem prawnika eksperta, kosztem responsywnej otwartości na społeczne wyzwania (trudne przypadki orzecznicze), to w judicial review wektory te będą odwrócone: zamiast oglądać się na swoje miejsce w systemie instytucjonalnym, prawnik (sędzia) powinien skoncentrować się na działaniu, które ma cechy interakcji w relacji jednostka-struktura. Struktura to wyrażony w tekstach prawnych zastany, hierarchiczny i poziomy (gałęziowy) porządek prawny z konstytucją na czele, wraz z odpowiednią obudową instytucjonalną (nauka, sądownictwo). Case prawny to z kolei dla sędziego wyzwanie na rzecz jego sprawiedliwego i społecznie akceptowalnego rozstrzygnięcia. Jeżeli struktura bezpośrednio dostępna (zbudowana na tekstach prawnych) nie daje podstaw dla dobrego rozwiązania kwestii prawnej, to sędzia powinien sięgać głębiej, do wiedzy wykształconej w orzecznictwie, w nauce prawa, $\mathrm{w}$ tym teorii wykładni, a nawet do filozofii prawa (konstytucjonalizm). Podjęte $\mathrm{w}$ oparciu o takie przesłanki rozstrzygnięcie będzie wzmacniać elementy tej struktury (zasada stare decision). Jeśli sędzia ma jednak do czynienia z tzw. hard case, to zastana struktura może okazać się niewystarczająca, a wtedy zmuszony będzie ją rozszerzyć, a nawet zmodyfikować pewne elementy zastanego porządku wiedzy w zakresie, jaki pozwoli rozstrzygnąć i uzasadnić rozważany przypadek. Pojawia się zatem miejsce na aktywizm sędziowski, uobecniający się w precedensach orzeczniczych wypełniających braki ustawodawstwa, na kreatywną interpretację tekstu czy tworzenie nowych pojęć doktrynalnych. Aktywność sędziów jest tu swoistą "grą" ujętą w ramy relacji między tym, co ogólne i tym, co szczegółowe ${ }^{80}$ : między ustawą, tekstem prawnym, zastanym rozumieniem pojęć z jednej strony i konkretnym, historycznym problemem orzeczniczym domagającym się osądu sprawiedliwego i zgodnego z odczuciem społecznym z drugiej strony. Można tu zatem mówić o responsywności prawa wobec społecznej rzeczywistości (w tym także samej konstytucji, rozbudowywanej w drodze poprawek kształtowanych pod znaczącym wpływem sygnałów płynących ze strony orzecznictwa), o responsywnej wykładni konstytucji oraz o pojęciach konstytucyjnych kształtowanych pod wpływem czynników pozaprawnych ${ }^{81}$. Być może, narażając się zapewne na nieco ryzykowne uproszenie, dałoby się wręcz powiedzieć, że spo-

80 Por. L. Garlicki, Sąd Najwyższy Stanów Zjednoczonych Ameryki: konstytucja - polityka - prawa obywatelskie, Wrocław-Warszawa-Kraków-Gdańsk 1982, s. 91.

81 Zob. M. Korycka-Zirk, op. cit. Autorka posługuje się zwrotem „responsywność pojęć konstytucyjnych na czynniki pozaprawne” (s. 183) oraz "metoda wykładni responsywnej w stosunku do aktualnego suwerena" (s. 293). 
łeczna i polityczna historia Stanów Zjednoczonych to w jakiej przynajmniej mierze również historia prawa kształtowanego z istotnym udziałem orzecznictwa amerykańskich sądów, w tym przede wszystkim Sądu Najwyższego; sądownictwa aplikującego konstytucję i zwrotnie kształtującego dorobek konstytucjonalizmu. Nieprzypadkowo nurt tzw. living constitution wyrósł na obszarze tej właśnie kultury prawnej.

Jeśli nawet przyjmiemy, że aktywizm konstytucyjny w doktrynie judicial review nie jest postawą powszechnie aprobowaną ${ }^{82}$, to doktryna ta pozwala nam na konkluzję bardziej zasadniczą i być może nawet o większej doniosłości dla perspektyw budowania dydaktyki akademickiej na bazie konstytucji i myśli konstytucyjnej. Warto bowiem zauważyć, że zasadnicze dla współczesnej teorii i filozofii prawa debaty, to - czy nam się to podoba czy nie - spory wokół wykładni prawa. W przypadku amerykańskiego rynku uprawiania ogólnej refleksji o prawie debaty te dotyczyły właśnie wykładni konstytucji. Jeżeli w Polsce dorobek teorii wykładni prawa - skądinąd bardzo znaczący - kształtowany był ze względu na potrzeby wykładni ustaw zwykłych, a wtórnie dopiero usiłowano adaptować rezultaty tych osiągnięć na obszarze wykładni konstytucji ${ }^{83}$, to kulturowy kontekst judicial review składnia do konkluzji przeciwnej: punktem wyjścia jest teoria (filozofia) wykładni konstytucji ${ }^{84}$. To przede wszystkim na gruncie wykładni konstytucji - poszukiwania właściwej metody jej interpretacji - pojawiły się, i nadal są szeroko dyskutowane, zasadnicze dla amerykańskiej doktryny wykładni spory między tekstualistami i intencjonalistami, między oryginalistami i zwolennikami living constitution. A wszystko to wyrastało z filozoficznej i politycznej debaty wokół zasadniczych - a niełatwych przecież do pogodzenia - wartości leżących u podstaw porządku prawnego: suwerenność wspólnoty versus ochrona praw jednostki, rządy prawa (władza sędziów) versus rządy oparte na większości parlamentarnej. Spór o metodę wykładni konstytucji stawał się przez to sporem o granice władzy w ramach dynamicznie (responsywnie, refleksyjnie) kształtowanej zasady jej trójpodziału. Spór prawny nie dawał się odseparować od sporu politycznego, a dogmatyczna analiza tekstu konstytucji od jej filozoficznego ugruntowania. To najlepsza chyba lekcja poglądowa, którą wynieść można dla prawniczej dydaktyki akademickiej, również w kontekście polskich sporów o praworządność, o status sądownictwa konstytucyjnego czy o granicę władzy opartej na większości parlamentarnej.

82 Zob. A. Tomza, Spór o poprawna interpretację Konstytucji Stanów Zjednoczonych. Od pasywizmu do aktywizmu sądowego, "Jurysprudencja” 2016, 7, passim.

83 Standardową frazą wyrażającą tę tendencję jest zwrot "specyfika” wykładni lub interpretacji konstytucji. Wprowadzający tekst do monografii Wykładnia konstytucji. Aktualne problemy i tendencje (pod red. M. Smolaka) autorstwa Sławomiry Wronkowskiej nosi tytuł O niektórych osobliwościach konstytucji i jej interpretacji (op. cit., s. 15 i n.). 
W perspektywie judicial review edukacja prawnicza będzie zatem polegała nie tylko na nabywaniu umiejętności rozpoznawania zastanej struktury wiedzy (identyfikacja źródeł prawa, znajomość technik egzegezy i wykładni tekstu, produkcja linii orzeczniczych), ale również zmierzać powinna do uczenia umiejętności jej kształtowania, aktywnego korygowania pod kątem wyzwań społecznych. Prawo i praktyka prawnicza - wraz z rejestrującą te domeny nauką i upowszechniającą jej osiągnięcia dydaktyką - są społecznie, więc i politycznie, zaangażowane już w swoim punkcie wyjścia. Prawnicze doświadczenie edukacyjne wyniesione z akademii - zgodnie z ideą F. Znanieckiego tzw. szkoły otwartej - zdają się również z punktu widzenia judicial review potwierdzać przekonanie, że nabyta w drodze edukacji wiedza przedmiotowa jest tylko jednym z czynników, który powinien kształtować kompetencje zawodowe i tożsamość prawnika. Reszta musi być zdobywana w grupowym i indywidualnym działaniu, w konfrontacji z prawniczą i społeczną rzeczywistością.

Argumenty, które prawnik pozyskuje z tekstu konstytucji i dostępnych mu osiągnięć konstytucjonalizmu, powinny dobrze korespondować z taką właśnie aktywną, permanentną i przedmiotowo nielimitowaną edukacją. To do tej bowiem dziedziny prawa i wiedzy prawniczej sędziowie oraz pozostali uczestnicy sporów prawnych odwołują się w bardziej skomplikowanych przypadkach orzeczniczych. Doktryna tzw. rozproszonego stosowania konstytucji pokazuje, że potencjalnie każdy skład sądzący, a właściwie również każdy inny decydent (urzędnik, przedsiębiorca, obywatel), w tym także uczestnicy relacji prywatnoprawnych (jednostka-jednostka ${ }^{85}$, mogą być postawieni w sytuacjach wymuszających na nich zainteresowanie się tekstem konstytucją i dorobkiem myśli konstytucyjnej. Pogłębiona o dorobek konstytucjonalizmu, w tym filozofii prawa i filozofii społecznej, wiedza o ustawie zasadniczej powinna być zatem oferowana każdemu absolwentowi studiów prawniczych, a na poziomie bardziej elementarnym stać się również powinna ważnym składnikiem edukacji powszechnej. Doniosłość wiedzy o tzw. normatywnym otoczeniu konstytucji ${ }^{86}$ skłaniać powinna do otwierania się dydaktyki prawa konstytucyjnego na elementy wiedzy o społeczeństwie, na refleksyjną analizę rozstrzygnięć sądowych komentowanych przez opinię publiczną, na towarzyszące im działania i postawy prawników, na zasady i wartości legitymizując prawo i orzecznictwo sądowe etc. Trudno byłoby chyba wskazać lepszy

85 Zob. R. Alexy, A Theory of Constitutional Rights, Oxford 2002, s. 352 i n.; mowa tu o koncepcji tzw. promieniowania konstytucji, o jej tzw. efekcie horyzontalnym. Zob. także E. Łętowska, Promieniowanie orzecznictwa Trybunatu Konstytucyjnego na poszczególne gatęzie prawa, [w:] M. Zubik (red.), Ksiega XX-lecia orzecznictwa Trybunału Konstytucyjnego, Warszawa 2006, s. 353 i n. 
przykład dla tzw. wewnętrznej (wiedza prawnicza, kultura prawna) i zewnętrznej (wiedza pozaprawna, kultura ogólna) integracji nauk prawnych oraz upowszechniającej jej osiągnięcia, otwartej edukacji prawniczej. Zasada prawnej supremacji konstytucji może zatem, jak sądzimy, korespondować z podobną ideą leżącą u podstaw kształtowania prawniczej dydaktyki akademickiej.

\section{Bibliografia}

Alexy R., A Theory of Constitutional Rights, Oxford 2002.

Amar A.R., American Constitutionalism - Written, Unwritten and Living, "Harvard Law Review" 2013, 126.

Baert P., Carreira da Silva F., Teorie społeczne w XX wieku i dzisiaj, Kraków 2013.

Bourdieu P., Passeron J.D., Reprodukcja. Elementy teorii systemu nauczania, Warszawa 2006.

Feinberg W., Soltis J.F., Szkoła i społeczeństwo, Warszawa 2000.

Garlicki L., Sąd Najwyższy Stanów Zjednoczonych Ameryki: konstytucja - polityka - prawa obywatelskie, Wrocław-Warszawa-Kraków-Gdańsk 1982.

Giddens A., Sutton P.W. (współpraca), Socjologia, wydanie nowe, Warszawa 2012.

Gromski W., Autonomia i instrumentalny charakter prawa, Wrocław 2000.

Jakimowicz W., Wyktadnia w prawie administracyjnym, Zakamycze 2006.

Kaczmarek P., Tożsamość prawnika jako wykonawcy roli zawodowej, Warszawa 2014.

Kaczorowski P., Carl Schmitt, jego nauka o konstytucji i kwestie suwerena-ustrojodawcy, „Teologia Polityczna Co Tydzień" 2016, 9, https://www.teologiapolityczna.pl/

Kelsen H., Haupteprobleme der Staatsrechtslehre: entwickelt aus der Lehre vom Rechtssatze, Aalen 1984.

Kelsen H., Istota i rozwój sądownictwa konstytucyjnego, Warszawa 2009.

Kelsen H., Reine Rechtslehre, 1934, przedruk: Tübingen 2008.

Koczanowicz L., Antagonizm, agonizm i radykalna demokracja. Koncepcja polityki Chantal Mouffe, [w:] Ch. Mouffe, Paradoks demokracji, Wrocław 2005.

Korycka-Zirk M., Filozoficznoprawny wymiar kontroli konstytucyjności, Torun 2017.

Kosieradzka E., Odrębności procesu interpretacyjnego publicznego prawa gospodarczego (ze szczególnym uwzględnieniem fazy walidacyjnej), [w:] L. Leszczyński (red.), Wykładnia prawa. Odrębności w wybranych gatęziach prawa, Lublin 2006.

Kustra A., Kelsenowski model kontroli konstytucyjności prawa a integracja europejska. Studium wptywu, Torun 2015.

Kustra E., Rozwojowy model tworzenia prawa, „Acta Universitatis Nicolai Copernici. Nauki Humanistyczno-Społeczne" 1996, z. 307.

Kwieciński Z., Dynamika funkcjonowania szkoły. Studium empiryczne z socjologii, Toruń 1995. Longchamps F., O używaniu pojęć w naukach prawnych, Zeszyty Naukowe Uniwersytetu Wrocławskiego, Prawo VII, Wrocław 1960. 
Łętowska E., Promieniowanie orzecznictwa Trybunału Konstytucyjnego na poszczególne gałęzie prawa, [w:] M. Zubik (red.), Księga XX-lecia orzecznictwa Trybunału Konstytucyjnego, Warszawa 2006.

McLaren P., Życie po szkołach. Wprowadzenie do pedagogiki krytycznej, Wrocław 2015.

Meighan R. (L. Barton i S. Walker), Socjologia edukacji, Torun 1993, cz. IV.

Mikiewicz P., Oblicza socjologii edukacji - w stronę syntetycznego modelu analiz, „Edukacja” 2017, 3.

Mikiewicz P., Socjologia edukacji. Teorie, koncepcje, pojęcia, Warszawa 2016.

Mouffe Ch., Paradoks demokracji, Wrocław 2005.

Neyman E., Wywiad z profesorem Pierre'em Bourdieu, [w:] P. Bourdieu, J.D. Passeron, Reprodukcja. Elementy teorii systemu nauczania, Warszawa 2006.

Nonet P., Selznick P., Law and Society in Transition. Toward Responsive Law, New York-Hagerstown-San Francisco-London 1978.

Peretiatkowicz A., Teoria prawa i państwa H. Kelsena, „Ruch Prawniczy, Ekonomiczny i Socjologiczny" 1937, 17(4).

Rozmaryn S., Konstytucja jako ustawa zasadnicza Polskiej Rzeczpospolitej Ludowej, Warszawa 1961.

Schmitt C., Nauka o konstytucji, Warszawa 2013.

Schmitt C., Pojęcie polityczności, [w:] C. Schmitt, Teologia polityczna i inne pisma, Warszawa-Kraków 2000.

Selznick P., The Jurisprudence of Communitarian Liberalism, [w:] P. van Seters (red.), Communitarianism in Law and Society, Oxford 2006.

Selznick P., The Moral Commonwealth: Social Theory and the Promise of Community, Berkeley-Los Angeles-London 1992.

Srokosz J., Komunitariańska wizja prawa responsywnego a koncepcja państwa prawa, [w:] M. Andruszkiewicz, A. Breczko, S. Oliwniak (red.), Filozoficzne i teoretyczne zagadnienia demokratycznego państwa prawa, Białystok 2015.

Stawecki T., Koncepcja autonomicznej wyktadni pojęć konstytucyjnych: od praktyki do teorii, [w:] T. Stawecki, J. Winczorek (red.), Wyktadnia konstytucji. Inspiracje, teorie, argumenty, Warszawa 2014.

Sulikowski A., Wspótczesny paradygmat sądownictwa konstytucyjnego wobec kryzysu nowoczesności, Wrocław 2008.

Święcicki Ł., Carl Schmitt i Leo Strauss. Krytyka pozytywizmu prawniczego w niemieckiej myśli politycznej, Radzymin 2016.

Tomza A., Spór o poprawna interpretację Konstytucji Stanów Zjednoczonych. Od pasywizmu do aktywizmu sądowego, "Jurysprudencja" 2016, 7.

Trzciński J., Konstytucja PRL a konstytucjonalizm socjalistyczny, [w:] K. Działocha (red.), Konstytucja PRL po 30 latach jej obowiazzywania, Wrocław 1985.

Trzciński J., Znaczenie autonomicznej wykładni konstytucji na przykładzie orzecznictwa sądów administracyjnych, [w:] M. Smolak (red.), Wyktadnia konstytucji. Aktualne problemy i tendencje, Warszawa 2016. 


\section{ANDRZEJ BATOR, PRZEMYSŁAW KACZMAREK}

Wronkowska S., O niektórych osobliwościach konstytucji i jej interpretacji, [w:] M. Smolak (red.), Wykładnia konstytucji. Aktualne problemy i tendencje, Warszawa 2016.

Wróblewski J., Krytyka normatywistycznej teorii prawa i państwa Hansa Kelsena, Warszawa 1955.

Zalewska M., Czy pragmatyka jest u Kelsena możliwa?, „Filozofia Publiczna i Edukacja Demokratyczna" 2013, 2(2).

Zalewska M., Problem zarachowania w normatywizmie Hansa Kelsena, "Jurysprudencja” $2014,1$.

Zapała J., Korporacje prawnicze jako agenda socjalizacji. Rozważania na przykładzie samorządu notarialnego, [w:] H. Izdebski, P. Skuczyński (red.), Etyka prawnicza. Stanowiska i perspektywy 2, Warszawa 2011.

Zemło M., Nowa socjologia edukacji, Białystok 1996.

Znaniecki F., Socjologia wychowania, t. 1, Warszawa 2001. 